\title{
LAND DISPUTES IN INDONESIA: SOME CURRENT PERSPECTIVES
}

\author{
Anton Lucas
}

\author{
I see \\ developed countries giving economic aid. \\ And as a result \\ many people from the third world \\ are losing their lands, \\ so the rich can play golf, \\ or so a dam \\ can give electric power \\ to industries with foreign capital. \\ And the unfortunate people, yes Lord, \\ get compensation \\ for every square meter of their land, \\ with money that has the same value \\ as a packet of American cigarettes.
}

W. S. Rendra, For the People of Rangkas Bitung ${ }^{1}$

\section{The "Land for the People" Calendar}

In March 1991 a student from a Yogyakarta activist women's group visited the Inter Universities Center office, to ask for a donation for her organization. Her group was one of nine sponsors of a calendar called "Land for the People" (Tanah untuk Rakyat). The calendar attracted considerable comment after she had left, as those in the office at the time crowded around, trying to guess which national political figures were being satirized there-not a difficult task. About a week later, the government suddenly banned the calender for "jeopardizing national security" and for insulting the President and the government of

An earlier version of this paper was presented at a conference on "Indonesian Culture, Asking the Right Questions," at the Flinders University of South Australia in Adelaide in October 1991. I would like to express my thanks to Nasikun, director of the Social Studies division of the Inter University Center at Gadjah Mada University, and Mochtar Mas'oed, the deputy director, for their continuing support of this research.

1 Pikiran Rakyat, December 31, 1990, reprinted in Problema, no.1 (March 1991), p. 13, issued by the Yayasan Buruh Membangun. 
Indonesia. The police interrogated thirteen students, university lecturers, journalists, and officials, mostly from Satya Wacana Christian University in Salatiga, and the artist who created the calendar went underground (and reportedly left the country). The nine nongovernmental organizations that had sponsored the calender publicly claimed collective responsibility, in an effort to counter criminal charges being brought against two student activists from a non-governmental organization based in Salatiga (the Geni foundation), who were backing farmers' requests for higher compensation in the region to be flooded by the Kedung Ombo dam. ${ }^{2}$

The Tanah untuk Rakyat calendar visualizes in cartoon form what the sponsors (and many others) believe to be a major social and political issue in Indonesia today-the question of land clearances or penggusuran tanah. Various scenes in the calendar illustrate characteristics of many of these recent conflicts; the arbitrariness of official policy, the political and physical intimidation of protesters, and the unsatisfactory methods and levels of compensation for the farmers who have been displaced. It depicts local government officials with wads of money bulging out of every pocket of their safari jackets, people being evicted at the point of a gun by nasty looking soldiers, with their land being fenced off with barbed wire. A large figure dressed in blue pours water into an unfilled hole labeled Kedung Ombo while holding a bag of money with "overseas debt" printed on it.

Underneath this collage of social commentary, the creators of the calendar summarize six recent clearance cases. These are at Mt Badega (south of Garut), Jatiwangi (near Majalengka), and Cimacan (in Cianjur kabupaten), all in the province of West Java; Belangguan (Situbondo kabupaten) in East Java; Kedung Ombo covering the kabupatens of Boyolali, Sragen, and Grobogan (Central Java); and Pulau Panggung subdistrict in South Lampung province. The facts about each case as given on the calendar, together with data on the Cilacap petrochemical factory and the Urip Sumoharjo urban redevelopment project in Surabaya, are summarized in Table 1 (p. 81). Before considering three of these cases in more detail, I would like to look briefly at the historical background and the legal position of clearance cases in the context of perceptions of land disputes in Indonesia today.

\section{Some Historical Background}

The penggusuran issue is closely tied to rights to land and land ownership which have long been a complex social issue in Indonesia. In the Hindu Javanese kingdom of Mataram before the coming of the Dutch, the ruler distributed land for the people and their descendants to cultivate, or as appanages to faithful followers in return for their loyalty to the king. In colonial times, the VOC and the colonial administration that succeeded it tried to make sense of the Javanese land-tenure system, for purposes of taxation and later for levying corvée. The eighteenth-century debates about rights to land in Java--regarding whether ownership of the land resided with the Sovereign (or the State), with proprietors who collected revenue and determined land use, with villages ( or hamlets), or with individual peasant cultivators-usually reaffirmed the rights of the sovereign power. ${ }^{3}$ The Agrarian Law of 1870, making it illegal for foreigners to own land, declared that all "unused" or unoccupied land belonged to the state, and could therefore be leased to European plantations, while village land could be rented from the village for up to three years. The

\footnotetext{
2 Kedaulatan Rakyat, March 19, 1991; Jawa Pos, March 19, 1991; "Kasus Kalender Aneh Bin Ajaib" a pamphlet explaining the backgrounds of the two students charged, and the activities of the Yayasan Geni, as well as providing a summary of local press commentary.

3 Robert Van Niel, "Rights to land in Java," in Dari Babad dan Hikayat sampai Sejarah Kritis: Kumpulan karangan dipersembahkan kepada Prof Dr Sartono, ed. T. Ibrahim Alfian et al. (Yogyakarta: UGM press, 1987), pp. 122, $135-48$.
} 
Table 1. Major Land Clearances in Indonesia 1989-1992

\begin{tabular}{|c|c|c|c|c|c|}
\hline Project and Location & $\begin{array}{l}\text { No. of families/ } \\
\text { total population } \\
\text { involved }\end{array}$ & $\begin{array}{l}\text { No. of houses/ } \\
\text { total area } \\
\text { expropriated }\end{array}$ & $\begin{array}{l}\text { Compensation } \\
\text { offer (rupiah) }\end{array}$ & $\begin{array}{l}\text { Status of project/ } \\
\text { total investment }\end{array}$ & Developer \\
\hline $\begin{array}{l}\text { Kedung Ombo dam } \\
\text { (Central Java) }\end{array}$ & $5390 / 30000$ & 5968 ha flooded & $\begin{array}{l}\text { Rp. } 300 / \mathrm{m}^{2} \\
\text { later increased }\end{array}$ & $\begin{array}{l}\text { irrigation of } 60000 \text { ha. } \\
22.5 \mathrm{MW} \text { of electricity } \\
\text { \$US76.5 million }\end{array}$ & government + World Bank \\
\hline $\begin{array}{l}\text { Urip Sumoharjo } \\
\text { urban redevelopment } \\
\text { (Surabaya) }\end{array}$ & $468 / 25000$ & $2348 / 265$ ha. & $\operatorname{Rp} 178-825,000 / \mathrm{m}^{2}$ & $\begin{array}{l}\text { offices, shopping center, } \\
\text { hotels, recreation }\end{array}$ & $\begin{array}{l}\text { government + PT Karya } \\
\text { Yudha Sakti (Sudwikatmono) }\end{array}$ \\
\hline $\begin{array}{l}\text { Petrochemical factory } \\
\text { Cilacap (Central Java) }\end{array}$ & $1400 / 3035$ & 200 ha. & $\begin{array}{l}\text { varies according to } \\
\text { class of land }\end{array}$ & $\begin{array}{l}\text { petrochemical factory. } \\
\text { Total investment } \\
\text { \$US1.5 billion }\end{array}$ & $\begin{array}{l}\text { Shell 52\%; Pertamina 15\%; } \\
\text { Bimantara } 12 \% \text {; C. Itoh 9\%; } \\
\text { Mitsubishi } 9 \% \text {; International } \\
\text { Finance Corporation, Asian } \\
\text { Development Bank 3\% }\end{array}$ \\
\hline $\begin{array}{l}\text { Airforce base } \\
\text { Jatiwangi (Majalengka) W. } \\
\text { Java }\end{array}$ & 2198 landholders & 1021 ha. & N/A & Disputed & \\
\hline Koto Panjang dam (Riau) & $4125 / 23000$ & $\begin{array}{l}12600 \text { ha. to be } \\
\text { flooded }\end{array}$ & rp. $30 / \mathrm{m}^{2}$ & $\begin{array}{l}114 \mathrm{MW} \text { of electricity } \\
\text { US } \$ 290 \text { million }\end{array}$ & $\begin{array}{l}\text { Japan's Overseas Economic } \\
\text { Development Fund (OEDF) }\end{array}$ \\
\hline $\begin{array}{l}\text { Golf course } \\
\text { Cimacan (Cianjur) }\end{array}$ & 287 farmers & $\begin{array}{l}33.4 \text { ha. cultivated } \\
\text { since } 1943\end{array}$ & $\begin{array}{l}\text { rp. } 30 / \mathrm{m}^{2} \text { increased to } \\
\text { rp. } 210 / \mathrm{m}^{2} .\end{array}$ & golfcourse + tourist park & $\begin{array}{l}\text { PT Bandung Asri Mulya } \\
\text { (BAM) }\end{array}$ \\
\hline $\begin{array}{l}\text { Tea plantation } \\
\text { Badega (Garut) } \\
\text { W. Java }\end{array}$ & $579 / 2500$ & $\begin{array}{l}498.6 \text { ha. cultivated } \\
\text { since } 1943\end{array}$ & $\begin{array}{l}\text { "gift" of } 0.12 \text { ha. per } \\
\text { family }\end{array}$ & tea plantation & PT Surya Andaka Mustika \\
\hline $\begin{array}{l}\text { Marines base } \\
\text { Belangguan (Situbondo) } \\
\text { E. Java }\end{array}$ & 200 families & $\begin{array}{l}140 \text { ha. cultivated } \\
\text { since } 1923\end{array}$ & rp. $200 / \mathrm{m}^{2}$ & marine training & PT Asia Budi Daya \\
\hline $\begin{array}{l}\text { Pulau Panggung, South } \\
\text { Lampung }\end{array}$ & 2376 families & $\begin{array}{l}476 \text { dwellings burnt } \\
\text { by local authorities }\end{array}$ & none offered & $\begin{array}{l}\text { reforestation }+ \text { coffee } \\
\text { plantations }\end{array}$ & local government \\
\hline
\end{tabular}


twentieth-century concept of adat law, as applied to land classified as village or communally owned land (tanah ulayat or tanah jasan), gave the so-called "autonomous self-regulating villages" power to make laws regarding land. Thus the 1870 Agrarian Law recognized a dual system of land laws: the Western concept of private ownership (eigendom); and longterm lease (erfpacht) through which state and village lands could be rented out to Western plantations. Although farmers still had rights to land, the power of the sugar interests in Java, for example, ensured that farmers were in effect "evicted" from their lands for the length of the sugar mill lease (approximately three years). Several of the well-publicized disputes in Indonesia today regarding land claims have occurred as a result of farmers cultivating land formerly rented under long-term lease arrangements which began during the colonial period. The disputes at Mt. Badega and Cimacan, for example, both concern land formerly leased to European plantations which was taken over during the Japanese occupation by local farmers.

Although all but one of the cases described in Table 1 relate to penggusuran of agricultural land for development projects, there are dozens of similar less-publicized cases which concern disputed urban land clearance. ${ }^{4}$ In Jakarta and Surabaya, the two main urban areas of Java, penggusuran of kampung people began to increase in the first decades of the twentieth century. During 1918, in the run-up to the opening of the People's Council (Volksraad), Sarekat Islam leaders attacked the Batavia Municipal Council for forcing people off their lands in the city's Menteng area "with only paltry compensation" to provide a new European residential area. Stricter housing regulations led to many kampung dwellers being forced from their homes, as houses that were below standard were demolished. ${ }^{5}$ Similar clearances were increasingly occurring in Surabaya, a city "originally built in large part on illegally acquired kampung land."6

During the Japanese occupation, in order to requisition the maximum amount of rice and other resources for their war effort, Japanese authorities returned land previously leased by European plantations (including the majority of sugar mills in Java) to the cultivation of wet rice. In the case of Jatiwangi, in 1943 the Japanese took over land to build an airstrip. After the end of the war, the previous owners reclaimed their land and began cultivating it, but in 1951, Indonesian airforce personnel took it over, forcibly removing the people, although it has never been used as an airforce base since.

From the declaration of Indonesian independence until the passing of the Basic Agrarian Law in 1960, the State acted to resume lands where colonial agrarian law had granted legal rights of cultivation to foreigners. In 1948 the Republican government revoked 40 sugar mill leases of land previously rented from the kratons of Yogyakarta and Surakarta by European companies, and negotiated new lease agreements with individual farmers. In 1958 the Indonesian government abolished what were called private lands (tanah partikelir)—created in Raffles' day-which saw 1,150,000 hectares mainly owned by British, Dutch, Arab, and Chinese interests either sold to the government or distributed to farmers. ${ }^{7}$

\footnotetext{
4 The National Assembly (DPR), until the third sitting of the 1990/91 Parliament session, recorded recieving 541 written complaints about land problems. Editor, December 21, 1991, p. 11.

${ }^{5}$ Susan Abeyasekere, Jakarta: A History (Singapore, Oxford University Press, revised edition 1989), pp. 106,122.

${ }^{6}$ William H. Frederick, Visions and Heat: The Making of the Indonesian Revolution (Athens, Ohio University Press, 1989), p. 8.

7 Selo Soemardjan, "Land Reform di Indonesia," in Dua Abad Penguasaan Tanah: Pola Penguasaaan Tanah Pertanian di Jawa dari Masa ke Masa, ed. Sediono M.P. Tjondronegoro and Gunawan Wiradi (Jakarta: Gramedia, 1984), pp. $104-5$.
} 


\section{The Basic Agrarian Law of 1960}

The Basic Agrarian Law (UUPA, Undang-Undang Pokok Agraria) no 1 of 1960, which replaced all previous colonial land legislation, is extremely comprehensive. The State, on behalf of the citizens of Indonesia, is responsible for the management of land, water, air, and all natural resources (article 1). Where not in conflict with national laws, adat or communal property rights are recognized and various categories of rights to land are spelled out (including ownership, exploitation, building and use rights). All rights to land have a social function (article 6). The act gives protection to the interests of the economically weak (article 11). Issues addressed by the legislation include absentee landholdings, the registration of ownership to land and procedures for legal sale and inheritance, and maximum and minimum limits to land holdings. The government is responsible for land use planning or zoning.

Under the Basic Agrarian Law the State granted and revoked rights to land. Article 18 stated that:

For the public interest (kepentingan umum), which includes the interest of the people (bangsa) and the state (negara), as well as the collective interest of the people (kepentingan bersama dari rakyat) rights to land can be revoked, with the payment of reasonable compensation (ganti rugi yang layak) according to regulations. ${ }^{8}$

The new act also specified that revocation of rights to land was by presidential decree only. In practice, this has been seldom used because later legislation (Permendagri [Peraturan Menteri Dalam Negeri] no 15/1975) set up local Land Release Committees (Panitya Pembebasan Tanah) to implement the process.

After 1965, with the exception of the 1961 law on sharecropping and land reform (which will not be discussed in this paper), regulations to implement the UUPA, were never enacted. Especially in Java, agrarian relations were politicized by the PKI-led land-reform campaign of 1963-1965 to implement part of the UUPA. In the aftermath of the 1965 attempted Coup the entire Basic Agrarian Law became tarred with the same PKI brush. This further weakened the bargaining power of farmers under the New Order, vis-à-vis the stronger capitalist economic forces who were looking for land. ${ }^{9}$ Furthermore, after 1971, the state discontinued its annual budgetary allocations to finance the land-reform program, giving the impression that agrarian reform was "no longer a government priority." 10 Yet today the UUPA is still on the statute books, and there are periodic calls for regulations to implement it. For example, such concepts as the "social function" of land, "public interest," and "reasonable compensation" have never been spelled out in a way that would enable land clearances to be more carefully regulated. Rather, new regulations have been formulated which landholders feel have encouraged development without protecting the rights of the economically weak proclaimed under the UUPA.

According to the UUPA, in order for the state to recognize title to land, all rights must be registered and certificates issued acknowledging category of ownership. This was the only way of providing legal security to landholders. While registration was made mandatory

\footnotetext{
8 Boedi Harsono, Undang-Undang Pokok Agraria: Sedjarah penjusunan isi dan pelaksanaanja (Jakarta: Djambatan, 1971), p. 431.

${ }^{9}$ Iman Soetiknja, Politik Agraria Nasional (Yogyakarta: Gadjah Mada Press, 1990), pp. 95-96.

10 Sartono Kartodirdjo, "Latar Belakang Masalah-Masalah Pokok," in Laporan Interim: Masalah Pertanahan (Jakarta: Kementerian Riset Republic Indonesia, 1978), p. 14.
} 
under the law, no time limit was set on registration of land. ${ }^{11}$ As many landholders have found, subsequent regulations have empowered the government to expropriate land against the landholders' wishes, even if a certificate to the rights has been issued.

\section{Issues Regarding Rights to Land}

In all the land clearance cases surveyed, including the six mentioned by the Tanah untuk Rakyat calendar, two common issues are clear. In the majority of cases under review landholders have never registered their lands, because both of the cost and of the bureaucratic procedures involved. Thus the only proof of ownership or cultivation rights is the length of time they have been cultivating the land and their payment of all financial obligations. In an open letter to the Indonesian parliament, farmers from Belangguan in East Java pointed out that "these have been our ancestors' lands (tanah leluhur), since 1923, when our grandparents cleared the forest, and every year since then we have paid taxes." 12

A second issue in all land clearance cases is compensation. One of the issues involved in the Kedung Ombo dam land clearance (see below) was the complaint that, if people had to leave their fertile ancestral wet-rice lands, the compensation should be adequate. There had been a culture of opposition to the Dutch in this region, where the graves of two folk heroes (important historical figures involved in the Diponegoro war of 1825-1830), as well as sacred sites connected with these heroes, were submerged along with thousands of family graves. Many elderly relatives, often in poor health, were reluctant to leave because of the ties with their land and their ancestors. In the Cilacap land dispute, dipossessed owners complained that the Rp. 1000 compensation for removal of a grave meant that many had to leave their family ancestors behind on the site of the new petrochemical factory. Protesting the inadequate compensation, landholders carried the exhumed remains of their relatives in coffins on the back of bicycles around the villages.

\section{Land Policy since 1965}

No decree, no set of regulations or law holds good in Indonesia when it comes to land appropriation. The land and the law belong to the powerful and the people with money. ${ }^{13}$

The issue of land appropriation in Indonesia, and the increasing commercialization of land, reflects a number of trends since the beginning of the New Order. As was mentioned earlier, agrarian reform is no longer the priority it was before 1966 . The early five-year development programs of the New Order government emphasized increasing agricultural output, and this has made land more productive and increased its value to farmers. Agricultural land close to major commercial centers has become valuable for joint venture projects with foreign investors. The rapidly increasing value of land as a commodity has attracted local speculators (cukong tanah, tengkulak), who buy up the land and resell it, making large profits. Although the Basic Agrarian Law made absentee land ownership illegal, such own-

11 Colin MacAndrews, Land Policy in Modern Indonesia: A Study of Land Issues in the New Order Period (Boston: Oelgeschlager, Gunn \& Hain, for the Lincoln Institute of Land Policy, 1986), p. 24.

12 The letter was signed with thumb prints by 80 landholders, with identity cards of 136 citizens of Belangguan village, "who request protection from a bomb threat." From student files of the Belangguan case.

13 Setiakawan, no.6 (July 1991), p. 12, English original. This issue of Setiakawan, the journal of SKEPHI, the NGO network for conservation in Indonesia, gives a wide-ranging coverage of recent land disputes throughout the country. 
ership is in fact increasing, and good agricultural land is being bought up by the urban middle class, as a form of investment in the future. ${ }^{14}$

Tourism, the garment industry, and the footwear industry are three rapidly expanding economic sectors that require land in close proximity to, if not within, the big urban centers. Government departments need land for office expansion. In urban areas Indonesian conglomerates have been working with local government authorities to buy land for hotels, shopping plazas, and office blocks. In rural areas, conglomerates have consolidated their control over former state forest areas which are being cleared for agricultural crops. ${ }^{15}$

Implementation of land-use policy is a complex process. It involves different government departments, including the Ministry of Home Affairs, and the BPN (Badan Pertanahan Nasional, National Council for Land Affairs) which now has national responsibility for land policy, replacing the former Directorate General of Agrarian Affairs. The dimensions of the problem of implementing land policy in Indonesia today are clear from comments made by the Indonesian Legal Aid Service (LBH). The number of laws, acts, regulations, and instructions which have been promulgated since the UUPA was passed in 1960 have made it difficult to give legal advice in land disputes. The Legal Aid Service has reported problems in keeping itself fully aware of new legislation being enacted at various levels. ${ }^{16}$ Local governments, on the one hand, should defend the rights of individual citizens, and, on the other, actively promote development projects in their respective regions. Let us briefly examine the main areas where conflict arises in the context of three of the case studies.

\section{The Cimacan Case}

"Don't value land cultivated for many years at only 30 rupiah per square meter!" Minister of Home Affairs Rudini's comment on compensation offered to 287 farmers of Rarahan hamlet, Cimacan village, Cianjur, West Java. ${ }^{17}$

The level of compensation for landholders who have been told that their lands are to be appropriated for development projects is the central issue in the Cimacan dispute. Article 18 of the Basic Agrarian Law states, as we have seen, states that the government must pay adequate compensation (ganti rugi yang layak), according to regulations which were never promulgated. Fifteen years later a Ministry of Home Affairs Regulation (Permendagri no. 15/1975) created Land Release Committees (Panitia Pembebasan Tanah) to determine the level of compensation for people who have lost their land to a private or government development project. These Committees are constituted in such a way that they have no landholders' representatives. So when a level of compensation is set for the land it is often below both market price and the cost to the farmer of finding alternative land of similar productivity. The obligatory deliberations (musyawarah) to reach an agreement on the price of the land are reduced to a meeting at the local village or district office when local officials inform landholders of the Committee's decision on compensation. There is no mechanism for solving disputes if the process of musyawarah does not result in agreement, nor is there an authority to whom the land owner can appeal. Under the UUPA of 1960 landholders

\footnotetext{
14 Kuntowidjoyo, "Keadilan Sosial di Pedesaan," in Prospek Pedesaan 1987, ed. Mubyarto et al. (Yogyakarta, P3PK UGM, 1987), pp. 109-15.

15 The cover story "Liem mengkavling Riau," appeared in Prospek, September 21, 1991, pp. 86-97.

16 Abdurachman, "Aspek2 Pokok Hukum Agraria," Radar 27 (September-October 1987): 16-17.

17 The compensation was being offered to farmers by a private developer building a golf course in Cimacan. Kompas, July 24, 1989, quoted in Arnold Purba, Biarkan Rakyat Bicara: Tangan Besi Merampas Tanah Kami. Pembelaan Didepan Pengadilan Negeri Bandung untuk Menjawab Semua Tuntutan Penguasa Negeri in kepada Mahasiswa Indonesia, (Bandung, January 27, 1990), p. 62
} 
who suffer financial loss could appeal to a court, but Permendagri 15/1975 does not give them this right. In the Kedung Ombo dispute, landholders who have sought justice through the local courts against the government have lost their cases. ${ }^{18}$ Under the same law, the village headman is a member of the Land Release Committee. He has to protect the interests of his people, but in the "era of development" policy of the New Order he must be supportive of government or private interests needing land for development projects.

The Cimacan dispute highlighted the powerlessness of farmers to fight unjust compensation unless supported by a powerful official, and the importance of the attitude of the village headman. In Cimacan village the headman declared that 33 hectares of land, originally held under a long term lease (erfpacht verponding) by a European plantation but since 1943 actively farmed by (in 1989) 287 farmers, was village land and therefore officially at his disposal. Without consulting the villagers concerned, this land was leased to a developer, PT Bandung Asria Mulia (BAM), for 30 years, for a golf course forming part of a local tourist park development. The 287 farmers affected had begun cultivating the land in 1943, paying a total annual rent of $\mathrm{Rp}$. 1.4 million to the village, although the village claimed to receive only Rp. 300,000. As the company was offering only token payment (referred to locally as uang pengjeujeuh), the dispute continued for several months. There was intervention from various notable figures, including Minister for Home Affairs Rudini, Minister Coordinator for Politics and Security Sudomo, and Chairman of the National Council for Land Affairs (Badan Pertanahan Nasional or BPN) Sony Harsono. None of these interventions helped the farmers, who in late August 1989 decided to cultivate their land again under a poster which read "We live off this land. Let us go on living as farmers!" The headman's comment was: "The land is owned by the village, so if the people are not given compensation it actually doesn't matter."19 The Cimacan farmers also took their case to the national parliament, the DPR, to which landholders often appeal for assistance in land disputes, and the matter was again referred to the BPN. However the construction of the golf course has apparently proceeded.

\section{The Kedung Ombo Project.}

... The implementation of the resettlement plans and land compensation rates [for the Kedung Ombo project] was left to local government, in particular the district [kabupaten] authorities. From the start confusion, uncertainty and secrecy marked the process, whether in the planning or the implementation stages. In the end, from the point of view of the majority of the villagers, the process was noteworthy only for the outright hostility which government officials showed them. ${ }^{20}$

Beginning in 1982 the provincial government of Central Java began setting compensation rates and developing resettlement plans for more than 5,000 families from 37 villages in 7 subdistricts who were to be moved for a huge dam financed largely by the World Bank. Construction started in October 1985, and flooding of 6,576 hectares of farmland began in January 1989. The functions of the Kedung Ombo dam include tourism, flood control,

18 Landholders who took their cases to court in Semarang and Boyolali, claiming compensation for loss of sawah, house gardens, houses, and other possessions, and for loss of two years harvest, claiming they had been unjustly smeared with ex-tapol (ex-political prisoner) stamped on their identity cards, lost their cases, and their appeal. Other cases are being prepared. Romo Mangunwijaya, "Situasi dan saran tentang resettlement penduduk Kedung Ombo sekarang," (Yogyakarta, February 20, 1991), pp. 8-9.

19 Kompas, July 22, 1989, quoted in Purba, Biarkan Rakyat Bicara, p. 61. For a summary of the Cimacan case see YLBHI [Yayasan Lembaga Bantuan Hukum] and JARIM [Jaringan Informasi Masyarakat], Laporan Khusus/Case Report, (Kedung Ombo, Kasus Arso, Cimacan), vol. 2 (June 1991), pp. 91-99. 
irrigating 70,000 hectares of new rice lands, and the production of 22.5 megawatts of electricity. ${ }^{21}$

Compensation rates paid to landholders were inadequate and never accepted as fair by the farmers, partly because the farmers themselves were never included in negotiations. The quality of the land in the resettlement sites in the region was much poorer, while villagers no longer could be persuaded to transmigrate to other islands. Although the dam has been flooded for over a year, and was formally opened by the President in March 1991, approximately 600 (now reported to be 1,000) families still live in the green belt above the water-line of the dam, now a vast inland lake. It was to these people that the President addressed his remarks at the opening ceremony, when he said that he understood how difficult it was for farmers to leave their ancestral farmlands, but that people were being asked to make sacrifices "for the greater good" (kepentingan yang lebih besar). Referring to those who had not moved, he said the government would not increase the compensation, because it would not be fair to those who had already accepted payment. He would also regret it if a group of them were to become known as resisters (kelompok mbalelo) in the future. The President told the assembled farmers and invited dignitaries that the people had two alternatives: to transmigrate to other islands, or to move their villages to land previously managed by the Forestry Department where they would be issued with certificates of title. ${ }^{22}$

The Kedung Ombo dam project highlights another set of conflicts which arise in compulsory land acquisition, namely relations between landholders and local government officials. Attitudes towards individual projects and the mechanism for solving disputes vary considerably between levels of local government. Officials often appear patronizing, manipulative, sometimes intimidatory. Since the beginning of the project officials have used threats and intimidation to persuade villagers to accept compensation rates and resettlement plans. Kedung Ombo residents had to sign a document with thumb prints after being told it related to taxation. The same document was produced later as evidence that the landholders had agreed to compensation offered by the government. Then a number of villagers, having submitted their personal identity cards for routine renewal, had them returned with stamped initials marking them as former political prisoners or members of now-banned organizations, making them vulnerable to all kinds of bureaucratic or political pressure. ${ }^{23}$

Indirect political pressure also comes from local DPRD (Regional People's Consultative Assemblies) which often seem uninformed about the facts and issues surrounding particular disputes. The chairman of Boyali kabupaten DPRD (which represents a large number of villages affected by the Kedung Ombo dam) said it was untrue that the Kedung Ombo families who refused to move and sought better compensation for their fertile rice lands were anti Panca Sila or anti-development. The Boyolali Golkar chairman said "There is no evidence that they are anti government, they are not yet aware [belum sadar]."24

\section{The Urip Sumoharjo Dispute}

The 26 hectares of urban land in Surabaya now under dispute are home to roughly 4,600 families or a total of 19,000 people, administered by seven kampung associations (RW or

20 Laporan Kasus/Case Report, vol.2 (June 1991), p. 22 (English original).

21 Tempo, May 25, 1991, p. 22.

22 Ibid.

${ }^{23}$ Laporan Kasus/Case Report, vol 2 (June 1991), p. 23

24 Stanley, "Seputar Kedung Ombo," typscript prepared for a seminar in Salam, Daerah Istimewa Yogyakarta, May 19-20, 1990, p. 154. 
rukun warga) under two different village administrations (kelurahan). Centrally located and accessible to public health and cheap public transport, the area is supplied with electricity and telephones, has good ground water, no wet-season flooding, and comparatively little pollution (it is not an industrial area). Being close to city markets, kampung people can buy basic necessities cheaply. The majority are self-employed in a wide range of activities, particularly running food-selling and motor-bike repair businesses. Also a minority of them work in the armed forces or in the government. Residents have inherited their houses and claim they have been living in the area --in Keputran, Pandegiling, and Kedondong kampungs - for up to five generations. They belong to no village or kampung elsewhere, and reject the idea they are illegal residents. ${ }^{25}$

The dispute originated with a fire in 1983 which destroyed the Horizon supermarket on Jl. Urip Sumoharjo and 81 kampung dwellings on the west side of this main Surabaya thoroughfare. The municipal government refused to allow the owners to rebuild their dwellings; instead, the ailing Mayor of Surabaya suddenly announced plans for kampung renewal, and a private developer was contracted to build flats. After living in makeshift accommodation for two years, people moved in and started paying rent to the government. ${ }^{26}$

Surabaya's "obsession to become a metropolis" has, since 1988, encouraged developers to invest in this provincial capital of East Java. This development has resulted in increasing competition to obtain land, and sky-rocketing prices, particularly after the municipal government declared the area part of a new central business district. Adjacent to the disputed land there are now four hotels, two shopping plazas, two banks, and an office block, while two commercial office towers and a 5-star hotel are either planned or under construction. 27

As with the other land clearance disputes, the main issue is compensation. The developer, PT Karya Yudha Sakti (a company controlled by the President's brother-in-law Sudwikatmono), offered the residents three choices: new high-density housing on the same site, alternative housing on the edge of the city, or cash payments. Most inhabitants chose cash, but rejected the amount of compensation offered by the Mayor of Surabaya, which was based on whether the site was classified as business or residential and on the quality of the building. In supporting the developers, the assistant to the Mayor of South Surabaya quoted verses of the Qur'an to explain that by accepting low compensation for their land the people showed that they were able "to live with a state of loss." 28

Local military officers have intervened without any success to help solve the dispute. One kampung head offered local residents cheap loans on condition they accepted the rates of compensation offered. Residents continually requested a meeting with the developer, but the developer denied that his company was acting as a (private) investor, but rather as a project contractor for the government. Local residents feel that once the government possesses the land it will sell it to the developer, although officials keep emphasizing that it is "a local government project." Why, then are the hotels, shops, office blocks, being financed privately? the people ask.

25 "Pembebasan Urip Sumoharjo,"typescript, November (?) 1991, p. 3.

26 Ibid., pp. 6-8.

27 "Jawa Timur 1991, Kebijakan dan Problema: Aib birokrasi ditengah melonjaknya Harga Tanah," Jawa Pos, December 24, 1991; "Pembebasan Urip Sumohario," p. 13.

28 "Pembebasan Urip Sumoharjo',"p. 25. The assistant mayor only quoted the first two verses "Demi masa sesungguhnya manusia itu dalam kerugian" but the Surat Al-'Ashr continues "kecuali orang-orang yang berimam dan ber'amal salih dan berwasiat dengan kebenaran dan berwasiat dengan kesabaran," 105: 1-3, in $\mathrm{H}$. Mahmud Junus, Tarjamah Al Quran Al Karim (Bandung: Al-Ma'Arif, 1988), p. 540. 
Appeals to the national parliament and to Minister of Home Affairs Rudini have also not produced a solution, although Rudini has visited Surabaya and talked with residents' action groups. As of the time of writing the dispute is still not settled.

\section{Attitudes of the Minister of Home Affairs}

National-level officials, and members of the Indonesian parliament often send out contradictory signals regarding land clearances. Minister of Home Affairs Rudini is in fact the most prominent national-level government official involved in land disputes, because his ministry, together with the National Council for Land Affairs, is responsible for the administration of the land clearances. In the Cimacan dispute discussed earlier, Rudini at first responded positively to the farmers' protests, but in the end he backed the authority of the local village headman and, by implication, the developer, advising farmers to accept the compensation offered.

Landholders who bring their complaints to the Ministry of Home Affairs seem to get a fair hearing from Rudini or his staff. At least his public statements indicate sympathy for their plight. He is often also critical of officials in his own ministry, saying that the numbers of protesters coming to the Ministry of Home Affairs in Jakarta with grievances about land show that local government has "failed to give leadership." ${ }^{29}$ He questions the meaning of public interest, asking if a supermarket is in the public interest, then in whose public interest. ${ }^{30} \mathrm{He}$ suggests that the term penggusuran should be replaced by the "purchase of land for development projects." ${ }^{1} 1$ In Cimacan he warned the village headman not to be a "victim of the flattery of businessmen," because in the end "it is the farmers who suffer." 32 In Surabaya Rudini listened to people whose land was being appropriated for hotel and office shopping plaza redevelopment, criticizing municipal officials who "have just read out their decision regarding compensation, without giving the people a chance to speak. ${ }^{\prime 33} \mathrm{He}$ has also told the press in Surabaya that "local government must not be the spokesperson for business,"34 and has declined the invitation of the Surabaya municipal government to lay the foundation stone for the Urip Sumoharjo development project, on the grounds that there is still no agreement on compensation between the government and the people who are being evicted. ${ }^{35}$ When over one hundred landholders from Cilacap arrived in the Ministry of Home Affairs, Rudini made an unscheduled appearance in the car-park, and in a much publicized dialogue, gave an impression of openness and a genuine willingness to listen to grievances. ${ }^{36}$ At the beginning of the Kedung Ombo protests he was receptive to student involvement. After students told him he was getting a one-sided version of the dispute, he agreed to open up alternative sources of information apart from official government channels, with a student task force formed to work with landholders in Kedung Ombo. At the same meeting, he told student leaders not to listen to outside influences and stated that the majority of the people who didn't want to move were ex-PKI. He promised to act immedi-

\footnotetext{
${ }^{29}$ Media, January 14, 1991; Institute of Legal Aid (LBH) newspaper files.

30 Angkatan Bersenjata, January 3, 1991; LBH newspaper files.

31 Pikiran Rakyat, January 3, 1991; LBH newspaper files.

32 Kompas, July 24, 1989, in Biarkan Rakyat Bicara, p. 62. However, after talking with the headman in question, Rudini backed down, saying that he only meant the project should be halted until the dispute was solved.

33 Media Indonesia, January 3, 1991, in Rakyat VS Shell: Pengalaman Kasus Tanah Rakyat Cilacap, distributed by Sekerep [Serikat Kesetiakawanan Rakyat Cilacapl (Yogyakarta, 1990).

34 "Pembebasan Tanah Urip Sumoharjo," p. 15

35 Retorika, 5, 2 (1991), p. 16.

36 Pos Kota, November 13, 1990, Sinar Pagi, November 13, 1990, in Rakyat VS.Shell.
} 
ately against government officials who manipulated compensation payments. ${ }^{37}$ Rudini's liberal attitude apparently was not reflected in decisions favorable to landholders.

Rudini's public statements are in contrast to those of provincial-level officials, and members of the provincial-level DPRDs. On November 13, 1990, the day after 400 landholders from Cilacap protested to the national parliament, Governor H. Ismail set up a 24-Hour Commando Post (Posko 24 jam), where people in Central Java could take their disputes concerning land. ${ }^{38}$ The Governor announced the cultural principle on which Posko was based, namely ono rembug, ya dirembug, in other words "discuss your problems with us, don't protest." 39

The Governor of Central Java in general reacts negatively to farmers' protests about low levels of compensation. He complained that the leaders of the Cilacap protests were "stirrers," not "real farmers," charging that the people who masterminded the Cilacap protests were the same as those who organized the Kedung Ombo dam actions. ${ }^{40}$ One of Governor Ismail's most publicized decisions was his refusal to give Catholic activist priest and novelist Y.B. Mangunwijaya permission to set up a school program for the 3,500 children who were unable to get to school after the flooding that occurred as the dam was filling. This publicized the plight of the inhabitants who had refused to move out of the region but had tried to dismantle their houses and move to higher ground before the water level reached them.

\section{Student Perceptions of Land Disputes}

Student groups have been involved in disputes with landholders over rights to land and over levels of compensation since 1989. All levels of government have been wary of outside influence, particularly that of students, and have tried to drive a wedge between the students and landholders. In Cilacap, security officers only allowed landholders holding ID cards as proof they were residents in the disputed area to meet the regional head to discuss level of compensation. The local government closed off the Kedung Ombo communities and refused to allow students to enter the region. However student involvement continued in a number of ways.

First, students provided support, through legal advice and information networks and through organization of many of the protest actions to the parliament and the Ministry of Home Affairs or to local government officials. Where there are detentions, or court cases pending (as in the Badega, Cilacap, and Kedung Ombo disputes), students have arranged legal aid. Student action groups formed around each land case provide first-hand accounts of developments, giving a different perspective from the ones appearing in the Indonesian daily press. Some student groups find places in educational institutions in their own cities for children of the community leaders with whom they are working.

\footnotetext{
37 See Stanley, Seputar Kedung Ombo, pp. 96-98.

38 Suara Merdeka, November 15, 1990 in Rakyat VS Shell.

39 Ibid., Media Indonesia, January 3, 1991 in Rakyat VS. Shell. "Ona rembug, ya dirembug" is the kind of advice Javanese parents would give recalcitrant children, "don't go and act foolishly, discuss it with your family first."

40 Governor Ismail calls the protesting landholders oknum2 WTS. WTS usually means prostitute (wanita tuna susila) but the Governor means waton sulaya, or talking in an argumentative way with negative results. He also calls the leadership of protests "jumping bedbugs" (kutu loncat) a reference to the same student leadership of different land disputes, and "sate sellers" who fan the flames of discontent. Suara Merdeka, August 11, 1990; Media Indonesia, August 14, 1990 in Rakyat VS. Shell.
} 
However, the students are split on the strategies to use in working with the people involved in the disputes. Some students regard disgruntled landholders as an instrument for provoking an issue around which political opposition can be mobilized. This view is described (at least by its opponents) as the rakyat sebagai alat provokasi approach.

Another approach emphasizes training cadres, based on the felt needs of the local people, or as one student put it: "We should be dealing with the issues rather than with the masses, organizing around issues; otherwise, the people are just a tool."41 Another student view is that student involvement should be aimed primarily at raising the consciousness of the rural poor concerning their rights, with the foremost aim to create an alliance between urban and rural poor.

Over the past eighteen months, student involvement in the landholders' dispute with the Indonesian Airforce in Jatiwangi has shown concrete results, at least according to the activists themselves. It is claimed that the people can cultivate their land without being "taxed" 30 percent of the harvest by the airforce; they now have greater access to all the disputed land; and a new commander of the local airforce base has announced publicly his willingness to enter a dialogue with farmers. ${ }^{42}$

Nevertheless, results in general have been disappointing, especially to the activists themselves who speak about the poor organizational skills of their fellow activists, poor management of funds, and competition between different factions for influence amongst village leaders. ${ }^{43}$ The same pattern of student involvement re-occurs in the disputes, with different groups competing with each other, with intrigues, no self-evaluation, overlapping of activities, and lack of focus. ${ }^{44}$ The relationship between student groups and NGOs, characterized by mistrust and lack of cooperation on both sides, also makes any joint action difficult.

\section{The Future}

The penggusuran tanah issue continues to simmer away in the lead-up to the election. Efforts by ICMI, the Indonesian Muslim Intellectuals Association, to find a solution to the problem of the remaining landholders who refuse to move from Kedung Ombo produced nothing concrete. Muslim cultural activist Emha Ainun Nadjib, who was promoting a role for the organization in the dispute, has resigned from ICMI in protest against the bureaucratic procedures followed, which prevented further compensation being offered; against the refusal of the Kedung Ombo project engineers to allow more than 50 percent of the green belt above the dam's high-water mark to be used for resettlement; and against the President's reference to those landholders who refused to move as resisters or protesters (kaum mbalelo).

There has been no follow-up to the promising statement made by Minister of Home Affairs Rudini in January 1991 that the Permendagri no 151975 would be reformed to construct a mechanism whereby compensation payments for landholders would be more equitably determined. ${ }^{45}$ Rudini's most recent proposal has been that compensation for

\footnotetext{
41 Interview with student activists, Yogyakarta, September 1991.

42 Suara Rakyat, no 7, July 1, 1991.

43 This has been a characteristic of the Cilacap case. "Pergulatan di Tengah Massa" (typescript, Yogyakarta, 1991), pp. 29-30.

44 "Perkembangan Permasalahan Kasus Tanah Jatiwangi" (typescript, Surabaya, October 11, 1990, student files).

45 Media Indonesia, January 3, 1991, LBH files.
} 
landholders should include replacement housing provided by the project developer who is buying the people's land. ${ }^{46}$

The broader question remains the social cost to the government of these continuing disputes, which began in the early 1980 s but which have greatly intensified since 1989 . Consultative processes and other formal procedures, whereby landholders whose legal and political position is weak obtain fair compensation, are not working in the majority of the disputes. Indeed, there has been press speculation that so-called vocal ABRI members of the National Assembly, such as Police Colonel Roekmini Koesoemasti, have lost their nomination as appointed members of the next parliament because of their public support for those who bring their land disputes to the DPR. ${ }^{47}$

Landholders still refuse to accept the decisions regarding compensation for their land which have been forced on them by local government and developers, although the land is often taken over anyway. The government fears that the disputes are being politicized by forces from outside the village, and indeed students are active in nearly all the land clearances, as are NGOs. National-level bureaucrats and members of the National Assembly, and most of the daily press, say they want change but the state seems powerless to implement it.

46 Editor, September 7, 1991.

47 Jakart Pos, April 1, 1992. 